\title{
ORIGINAL ARTICLE \\ First record of a piebald Bates's Slit-faced Bat, Nycteris arge (Chiroptera: Nycteridae) from Equatorial Guinea, Central Africa
}

\author{
Diogo F. Ferreira ${ }^{1,3,}{ }^{,}$, Laura Torrent ${ }^{2,3}$, Andreanna J. Welch ${ }^{3,4}$, Jared D. Wolfe ${ }^{3,5}$, Kristin Brzeski ${ }^{3,5}$, \\ Luke L. Powell ${ }^{3,4,6}$
}

\author{
${ }^{1} \mathrm{CIBIO}-\mathrm{InBIO}$, Research Centre in \\ Biodiversity and Genetic Resources, \\ University of Porto, Campus de Vairão, \\ 4485-661 Vairão, Portugal. \\ ${ }^{2}$ Natura Montfred, J. M. Gironella i Pous, \\ 1-3, 17005, Girona, Spain. \\ ${ }^{3}$ Biodiversity Initiative, 133 Washington \\ St., Belmont, MA 02478, USA \\ ${ }^{4}$ Department of Biosciences, Durham \\ University, South Road, Durham, DH1 \\ 3LE, UK.
}

\begin{abstract}
Chromatic disorders may disrupt adaptive coloration and reduce animals' capacity to survive and produce young. These disorders have been documented widely for bats across the globe. However, most of these cases are concentrated in regions with well-studied faunal communities, such as Europe or North and South America, with little documentation of chromatic disorders in regions such as Central Africa. We captured a bat in mainland Equatorial Guinea, Central Africa, with distinct white patches on its body and normally pigmented eyes. Here, we report the first recorded case of piebaldism documented in Central Africa for the Nycteridae family, and the first case worldwide for Nycteris arge Thomas, 1903.
\end{abstract}

${ }^{5}$ Michigan Technological University,

School of Forest Resources and Environmental Science, Houghton, MI 49913, USA.

${ }^{6}$ Institute of Animal Health and Comparative Medicine, Graham Kerr Building, University of Glasgow, Glasgow, G128QQ, UK.

*Corresponding author: ferreiradfa@gmail.com

DOI: https://doi.org/10.14709/BarbJ.13.1.2020.14

Keywords: Africa, bats, chromatic disorder, leucism, piebaldism

\section{INTRODUCTION}

Mammalian colouration is largely the result of melanin deposition in the skin, hair, and eyes (Fertl \& Rosel 2002). Chromatic disorders occur when abnormal pigmentation causes anomalous colouration of cells, which can occur on any part of the body (Rook et al. 1998). This phenomena has been reported in a wide variety of mammal groups such as Rodentia (Jung \& Slough 2012, Brito \& Valdivieso-Bermeo 2016), Otariidae (Acevedo \& Aguayo 2008, Wege et al. 2015), Cetacea (Koper et al. 2017) and Chiroptera (Cichocki et al. 2017, Zortéa \& Cristina Silva 2017, Hernández-Aguilar \& Santos-Moreno 2018).

Mammalian coloration is integral for important behaviours such as crypsis and inter- and intra-specific communication (Caro 2005). Chromatic disorders may disrupt these behaviours and thus affect the ability to evade predators, hunt, or reproduce, thereby reducing the capacity to survive and produce young (Caro 2005). Given the deleterious nature of chromatic disorders, they are rarely encountered in nature. Their presence may indicate a rare individual with low fitness or potentially a mutation leading to an adaptive, new phenotype (Clarke et al. 1985).
As such, documenting the occurrence of rare or emerging chromatic disorders can identify emergent and important processes in natural systems.

Chromatic disorders are typically associated with two phenomena: 1) abnormal biosynthesis and deposition of melanin in the skin/hair follicles, resulting in darker individuals or with atypical skin/fur coloration (e.g. golden, yellowish or reddish); and 2) lack of melanin in the skin/hair follicles, resulting in all-white or patchy individuals. Leucism is a type of hypopigmentation that produces all-whitish coloration of hair follicles and/or skin (Lucati \& LópezBaucells 2017). However, an irregular lack of pigmentation on an otherwise normal-coloured animal (i.e., whitish fur/ skin patches) is known as a "piebald" phenotype (Acevedo et al. 2009). Piebald animals typically have patchy whitish spots with normal eye colouration, contrary to albinism where animals are all-white with red eyes (Davis 2007, Abreu et al. 2013, Lucati \& López-Baucells 2017).

In bats, chromatic disorders have been observed in at least 609 individuals belonging to 115 species encompassing 10 families (Lucati \& López-Baucells 2017). Piebaldism, with 269 known cases, comprises almost half of all observations, 


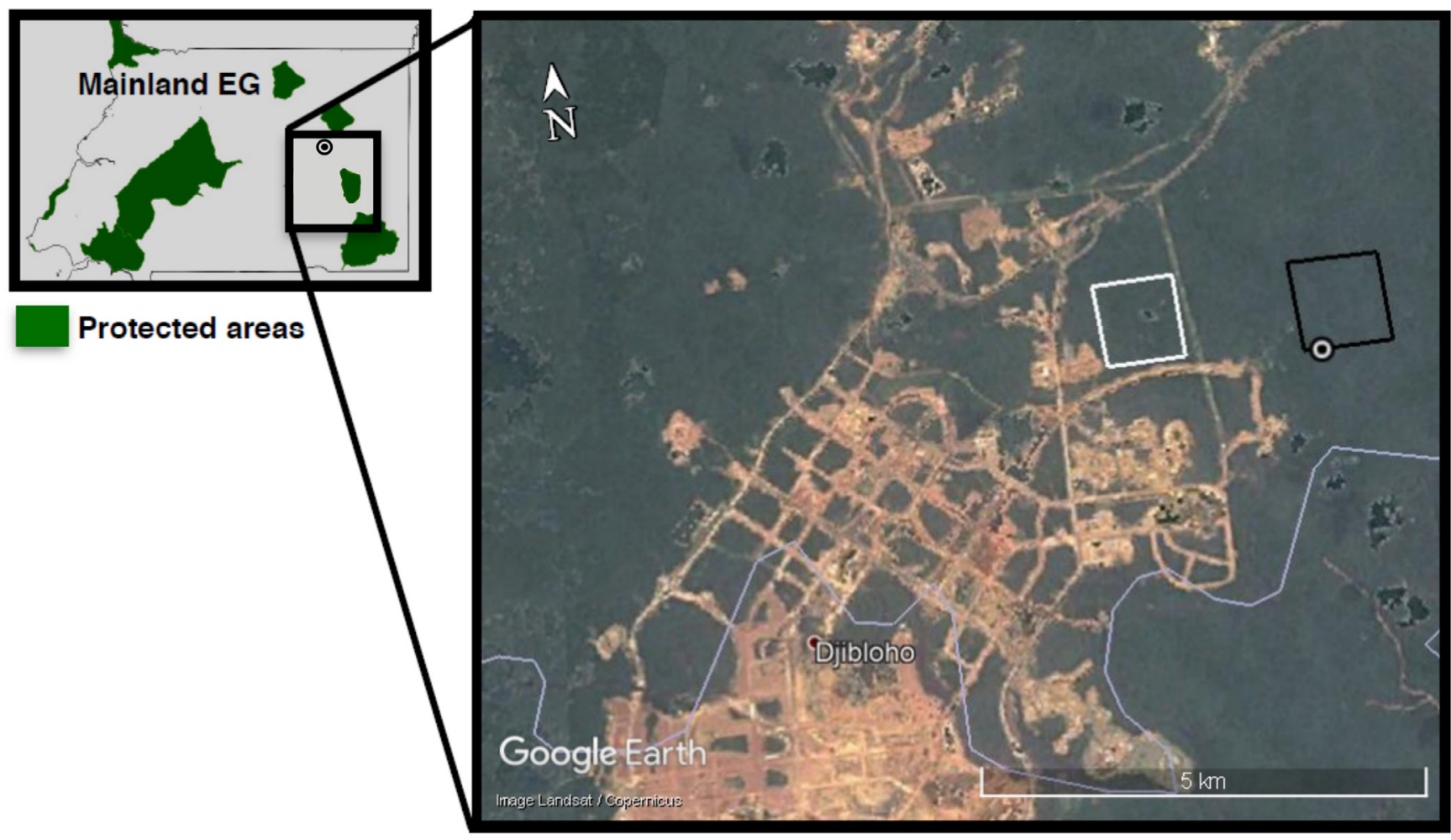

Fig. 1 - Map of the study area in Equatorial Guinea, Central Africa. Squares represent two sampling plots: primary forest (black square) and secondary forest (white square). The white dot represents the sampling site where the piebald bat was captured. Protected areas comprise several natural reserves, scientific reserves, and national parks.

while leucism and albinism have only 11 and 152 cases respectively (Lucati \& López-Baucells 2017). Despite the high number of cases reported globally, only 25 were from Africa, of which only one was in Central Africa. Thus, the reporting rate of chromatic disorders is low on this continent that harbours more than $20 \%$ of the world's bat species (ACR 2019). The paucity of reports is likely due to the relatively minimal amount of research in Central Africa compared to other regions (Malhi et al. 2014, Lucati \& López-Baucells 2017). Lucati \& López-Baucells (2017) listed all known cases of chromatic disorders for 16 different African bat genera, including the Nycteris genus. Five cases of hypopigmentism were detected in this genus with one case of albinism in Central Africa and four cases of piebaldism in East Africa, but no abnormal pigmentation has been recorded for Nycteris arge Thomas, 1903. Here we report the first case of piebaldism in the species $N$. arge, representing the first case of piebaldism for the Nycteridae family in Central Africa.

\section{MATERIAL AND METHODS}

We conducted this study in mainland Equatorial Guinea, approximately $5 \mathrm{~km}$ from the town Oyala, also known as Djibloho or more recently, Cuidad de la Paz: the yet-to-open new capital city of Equatorial Guinea. The area is dominated by a fragmented landscape composed of patches of primary and secondary forest, with small villages interspersed. Elevation of the area sits at 650 to $680 \mathrm{~m}$ above sea level and is characterized by two dry seasons: one between December and February and a second between June and August. This survey was part of a larger project aimed at understanding and quantifying bat biodiversity between tropical primary and secondary forests.
We conducted bat mist-netting in January 2018, in one 100 ha primary and one 100 ha secondary experimental forest plots (Fig. 1). Plots were separated by $1.5 \mathrm{~km}$; sampling sites were separated by at least $200 \mathrm{~m}$ in each plot. We sampled bats using 15 ground-level mist nets of 12 $x 3.2 \mathrm{~m} \mathrm{(20} \mathrm{mm} \mathrm{mesh)} \mathrm{placed} \mathrm{along} \mathrm{linear} \mathrm{transects.} \mathrm{Netting}$ was conducted during two periods: from 06:30 to 12:30 PM and from 04:30 to 06:30 AM. We measured and recorded forearm, ear and tail length, weight, sex, and age (adult/ juvenile) for each captured bat. Sexual activity was assessed by observing testicle and nipple size for males and females, respectively.

Although morphological measurements match with the description of $N$. arge (see Hayman \& Hill 1971), we note that there is a small probability the species could be confused with other Nycteris species. To confirm the taxonomic identification, we conducted genetic analyses. We extracted DNA from a wing punch using the DNEasy Blood and Tissue kit (Qiagen) according to the manufacturer's protocol. We then amplified a portion of the mitochondrial cytochrome $b$ gene using the primers Molcit-F and MVC16-R. The PCR reaction contained $1 \mathrm{X}$ Multiplex Master Mix (Qiagen), $0.5 \mu \mathrm{M}$ of each primer and $1 \mathrm{uL}$ DNA extract. The thermal cycling profile began with a 5 minute step at $95^{\circ} \mathrm{C}$, followed by 40 cycles of $95^{\circ} \mathrm{C}$ for $30 \mathrm{sec}, 50{ }^{\circ} \mathrm{C}$ for $1 \mathrm{~min}$, and $72{ }^{\circ} \mathrm{C}$ for $30 \mathrm{sec}$, with a final step of $72^{\circ} \mathrm{C}$ for $10 \mathrm{~min}$. PCR products were cleaned using the Qiaquick PCR Purification Kit, and Sanger sequenced in both directions on an ABI3700.

Quality control was conducted in Sequencher 5.1, and the final sequenced region comprised $489 \mathrm{bp}$ of the cytochrome b gene for 109 taxa. The sequence was then combined with the cytochrome $b$ sequences from clades $1 B$, 
2A, and 2B from Demos et al. (2019) and Nycteris thebaica as the outgroup. The analysis included 8 species from 21 clades. Sequences were aligned using MAFFT v 7 (Katoh \& Standley 2013) and the HKY + I + G model was selected as the best fitting nucleotide substitution model using the Akaike Information Criterion in the program jModelTest 2 (Guindon \& Gascuel 2003, Darriba et al. 2012). Phylogenetic trees were constructed using MrBayes 3.2 (Ronquist et al. 2012). Two runs were conducted each with 10 million generations and $10 \%$ burn-in. Convergence was assessed using Tracer 1.5 (Suchard et al. 2018) with ESS for all parameters in both runs being greater than 1000 . Trees were also constructed using RAxML black box (Kozlov et al. 2019) with the default $\mathrm{GTR}+\mathrm{G}$ substitution model and 1000 bootstraps.

\section{RESULTS AND DISCUSSION}

We captured 48 bats belonging to 15 different species of 8 genera during our sampling period. Of the 15 bats captured from the genus Nycteris, four were identified as Nycteris arge Thomas, 1903 and only one individual captured on January 15, in the primary forest, showed signs of atypical coloration. Normally $N$. arge has loose and fluffy pelage with pelage variable in colour. Dorsal pelage can be medium brown, rusty-brown or dark brown. Ventral pelage has similar colour but always paler than dorsal pelage (Happold \& Happold 2013).

We obtained $489 \mathrm{bp}$ of DNA sequence for the abnormal individual. The sequence is deposited in NCBI under accession number MT829307. Overall, the topology of both the maximum-likelihood and the Bayesian phylogenetic trees were congruent. Both phylogenetic trees placed the piebald bat within the $N$. arge 1 clade with good support (bootstrap support $>70$ and a posterior probability of 1 , respectively; Fig. 1 Supplementary Material). However, we highlight that $N$. arge belongs to a complex of four species ( $N$. nana, $N$. intermedia and $N$. major) where only $N$. arge and $N$. nana have published DNA sequences. Although there may be the possibility of misidentification with $N$. intermedia and $N$. major, the former has a smaller forearm and the latter has a bigger forearm and is not known to occur in Equatorial Guinea (Happold \& Happold 2013, ACR 2019). Hence, based on the morphological and genetic data $N$. arge is the most likely identification.

The abnormal individual we captured had three atypical white patches across the body: one small patch in the genital area, a bigger one extending from the chest to the right side of the body and one forming a white mask in the face (Fig. 2). The rest of the body, eyes and wings showed normal coloration. The bat was an adult male with no sign of sexual activity and with the following morphological measurements: forearm $40.9 \mathrm{~mm}$; ear $23.2 \mathrm{~mm}$; tail 51.6 $\mathrm{mm}$ (Fig. 2).

The chromatic disorder we observed in the bat was classified as a case of piebaldism, based on Lucati \& LópezBaucells (2017). Although piebaldism is a hereditary trait and we could not confirm its life history, we considered piebaldism as the most accurate term reflecting the condition observed. Our new record complements other available data in Central Africa, one of the least-studied regions of the

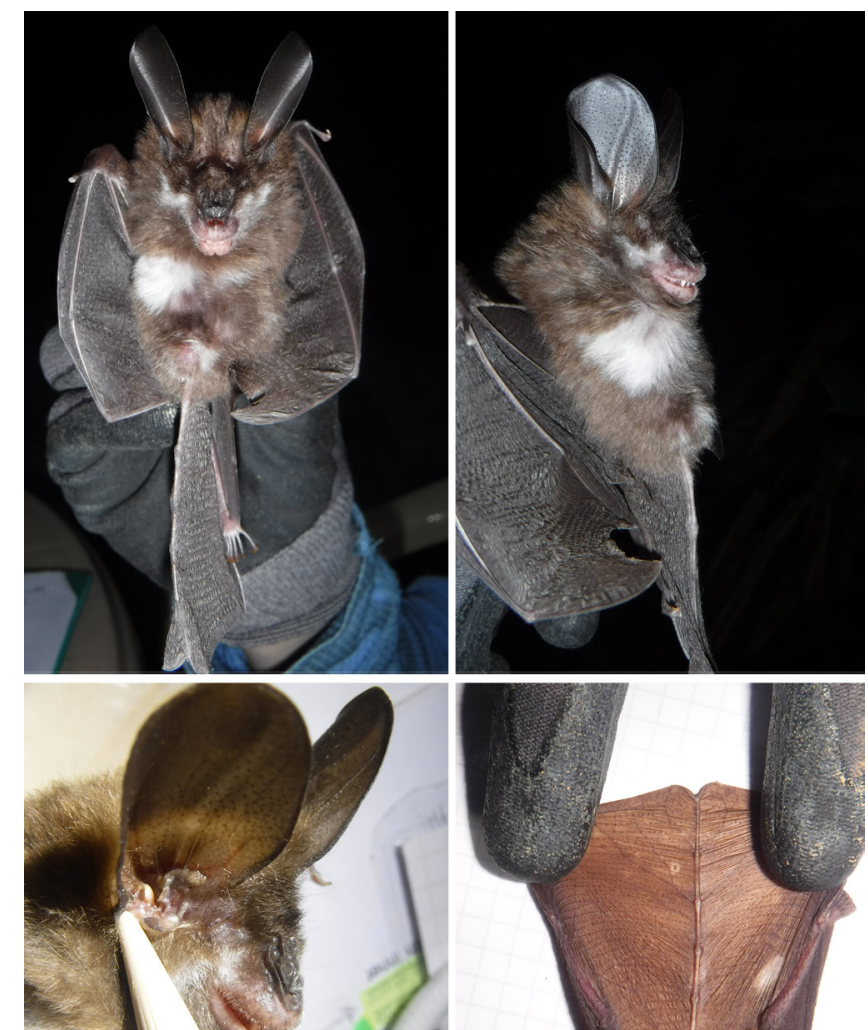

Fig. 2 - Frontal (top left) and profile (top right) picture of the piebald Nycteris arge. Bottom pictures show some diagnostic characters for this genus and species, tail ending in a T-shape (bottom right) and tragus (bottom left) respectively.

world, supporting the assumption that chromatic disorders may in fact be evenly spread on a geographical scale (Lucati \& López-Baucells 2017). Five other cases of hypopigmentism were previously identified in the Nycteridae family: one albinistic N. nana (K. Andersen, 1912) in Democratic Republic of the Congo (Verschuren 1955) and four piebald $N$. thebaica E. Geoffroy, 1818 in Tanzania (Howell 1980). Although one case of hypopigmentation was detected in Central Africa, it was a case of albinism and not piebaldism. Hence, this piebald $N$. arge is the first record of a hypopigmentation for this species and the first case of piebaldism for the Nycteridae family in Central Africa.

Although hypopigmentation can have detrimental effects on the fitness of animals, our single capture contributes little to our understanding of dichromatic disorder and their effect on bat fitness and survival (Lucati \& López-Baucells 2017). Hypopigmentation can disadvantage individuals by reducing reproduction while increasing susceptibility to predation (Caro 2005); however, documented cases of bats with chromatic disorders typically report healthy adult individuals (e.g. Sánchez-Nernández et al. 2010, HernándezAguilar \& Santos-Moreno 2018), and in some cases even pregnant individuals (Treitler et al. 2013). The piebald $N$. arge that we captured was a normal sized adult and did not exhibit signs of poor health, supporting the notion that chromatic disorders may not be strongly detrimental to bats. Bats mainly use dark sites to roost and are more active at night, using echolocation for foraging and orientation, which may help to explain why pigmentation may have little effect on predation or social behaviour. Nevertheless, studies focusing on survival and reproduction of bats with abnormal pigmentation should be undertaken before broader inferences can be made. 


\section{ACKNOWLEDGMENTS}

We thank the trainees and field assistants that helped collecting data. Field work was conducted in conjunction with the Instituto Nacional de Desarrollo Forestal y Manejo del Sistema de Áreas Protegidas (INDEFOR-AP) and the Amigos de la Naturaleza y del Desarrollo de Guinea Ecuatorial (ANDEGE), specifically coordinated with Fidel Esono Mba Eyono and Gabriel Ngua Ayecaba. We thank Stonehill Education and UNICON for providing housing at the Afro-American University of Central Africa. We also thank Terry Demos for sharing DNA sequences of Nycteris bats. Funding was secured by Biodiversity Initiative (http:// biodiversityinitiative.org/) - we thank the many donors to this charity organization. This research was conducted under a permit from INDEFOR-AP (Equatorial Guinea's Protected Areas Program).

\section{REFERENCES}

ABREU, M. S. L., MACHADO, R., BARBIERI, F., FREITAS, N. S. \& OLIVEIRA, L. R. (2013). Anomalous colour in Neotropical mammals: a review with new records for Didelphis sp. (Didelphidae, Didelphimorphia) and Arctocephalus australis (Otariidae, Carnivora). Braz. J. Biol., 73(1): 185-194. https://doi.org/10.1590/S151969842013000100020

ACEVEDO, J. \& AGUAYO, M. (2008). Leucistic South American sea lion in Chile, with a review of anomalously color in otariids. Rev. biol. mar. oceanogr., 43(2): 413-417. https://doi.org/10.4067/S0718-19572008000200017

ACEVEDO, J., TORRES, D. \& AGUAYO-LOBO, A. (2009). Rare piebald and partially leucistic Antarctic fur seals, Arctocephalus gazella, at Cape Shirreff, Livingston Island, Antarctica. Polar Biol., 32: 41-45. https://doi. org/10.1007/s00300-008-0500-6

ACR. (2019). African Chiroptera Report 2019. AfricanBats NPC, Pretoria.

BRITO, J. \& VALDIVIESO-BERMEO, K. (2016). First records of leucism in eight species of small mammals (Mammalia: Rodentia). Therya, 7(3): 483-489. https://doi. org/10.12933/therya-16-408

CARO, T. (2005). The Adaptive Significance of Coloration in Mammals. BioScience, 55(2): 125-136. https://doi. org/10.1641/0006-3568(2005)055[0125:TASOCI]2.0. $\mathrm{CO} ; 2$

CICHOCKI, J., LESIŃSKI, G., PIKSA, K., WAŻNA, A., WARCHAŁOWSKI, M., BATOR, A., GOTTFRIED, I., GOTTFRIED, T., GUBAŁA, W., JAROS, R. et al. (2017). Aberrant colouration in bats from Poland. North West. J. Zool., 13(2): 303-310.

CLARKE, C. A., MANI, G. S. \& WYNNE, G. (1985). Evolution in reverse: clean air and the peppered moth. Biological Journal of the Linnean Society, 26(2): 189-199. https:// doi.org/10.1111/j.1095-8312.1985.tb01555.x
DARRIBA, D., TABOADA, G. L., DOALLO, R. \& POSADA, D. (2012). jModelTest 2: more models, new heuristics and parallel computing. Nat. Methods, 9: 772. https://doi. org/10.1038/nmeth.2109

DAVIS, J. N. (2007). Color abnormalities in birds: a proposed nomenclature for birders. Birding, 39: 36-46.

DEMOS, T. C., WEBALA, P. W., KERBIS PETERHANS, J. C., GOODMAN, S. M., BARTONJO, M. \& PATTERSON, B. D. (2019). Molecular phylogenetics of slit-faced bats (Chiroptera: Nycteridae) reveal deeply divergent African lineages. J. Zool. Syst. Evol. Res., 57(4): 1019-1038. https://doi.org/10.1111/jzs.12313

FERTL, D. \& ROSEL, P. E. (2002). Albinism. In: Encyclopedia of marine mammals. ed.: Academic Press. San Diego, California, United Sates of America, p.16-18.

GUINDON, S. \& GASCUEL, O. (2003). A simple, fast, and accurate algorithm to estimate large phylogenies by maximum likelihood. Systematic Biology, 52(5): 696704. https://doi.org/10.1080/10635150390235520

HAPPOLD, M. \& HAPPOLD, D. C. (2013). Mammals of Africa Volume IV: Hedgehogs, shrews and bats. ed.: Bloomsbury Publishing. London, United Kingdom, 800 pp. https:// doi.org/10.5040/9781472926944

HAYMAN, R. W. \& HILL, J. E. (1971). Order Chiroptera. In: The mammals of Africa: an identification manual. Part I. ed.: Smithsonian Institute Press. Washington, United Sates of America, p.1-73.

HERNÁNDEZ-AGUILAR, I. \& SANTOS-MORENO, A. (2018). First records of hypopigmentation disorders in the Peters' ghost-faced bat Mormoops megalophylla (Chiroptera, Mormoopidae). Mammalia, 82(6): 618-621. https://doi. org/10.1515/mammalia-2017-0075

HOWELL, K. M. (1980). Abnormal white colouration in three species of insectivorous African bats. Journal of Zoology, 191(3): 424-427. https://doi. org/10.1111/j.1469-7998.1980.tb01472.x

JUNG, T. S. \& SLOUGH, B. G. (2012). Isabelline Coloration in American Red Squirrels (Tamiasciurus hudsonicus) from the Yukon. Northwestern Naturalist, 93(2): 162-164. https://doi.org/10.1898/nwn12-07.1

KATOH, K. \& STANDLEY, D. M. (2013). MAFFT Multiple Sequence Alignment Software Version 7: Improvements in Performance and Usability. Molecular Biology and Evolution, 30(4): 772-780. https://doi.org/10.1093/ $\mathrm{molbev} / \mathrm{mst010}$

KOPER, R., DROST, E. \& PLÖN, S. (2017). First Sighting of a Leucistic Humpback Whale (Megaptera novaeangliae) in South African Coastal Waters. Aquatic Mammals, 43(3): 331-334. https://doi.org/10.1578/AM.43.3.2017.331 
KOZLOV, A. M., DARRIBA, D., FLOURI, T., MOREL, B. \& STAMATAKIS, A. (2019). RAxML-NG: a fast, scalable and user-friendly tool for maximum likelihood phylogenetic inference. Bioinformatics, 35(21): 4453-4455. https:// doi.org/10.1093/bioinformatics/btz305

LUCATI, F. \& LÓPEZ-BAUCELLS, A. (2017). Chromatic disorders in bats: a review of pigmentation anomalies and the misuse of terms to describe them. Mam. Rev., 47(2): 112-123. https://doi.org/10.1111/mam.12083

MALHI, Y., GARDNER, T. A., GOLDSMITH, G. R., SILMAN, M. R. \& ZELAZOWSKI, P. (2014). Tropical Forests in the Anthropocene. Annu. Rev. Environ. Resour., 39: 125-159. https://doi.org/10.1146/annurevenviron-030713-155141

RONQUIST, F., TESLENKO, M., VAN DER MARK, P., AYRES, D. L., DARLING, A., HÖHNA, S., LARGET, B., LIU, L., SUCHARD, M. A. \& HUELSENBECK, J. P. (2012). MrBayes 3.2: efficient Bayesian phylogenetic inference and model choice across a large model space. Systematic Biology, 61(3): 539-542. https://doi.org/10.1093/sysbio/sys029

ROOK, A., WILKINSON, D. S., EBLING, F. J. G, CHAMPION, R. \& BURTON, J. (1998). Textbook of Dermatology 6th. ed.: Blackwell Science. Boston, Massachusetts, United States of America, 3683 pp.
SÁNCHEZ-NERNÁNDEZ， C., ROMERO-ALMARAZ, M. DE L., TABOADA-SALGADO, A., ALMAZÁN-CATALÁN, J. A., SCHNELL, G. D. \& SANCHÉZ-VÁZQUEZ, L. (2010). Five albino bats from Guerrero and Colima, Mexico. Chiroptera Neotropical, 16(1): 541-545.

SUCHARD, M. A., LEMEY, P., BAELE, G., AYRES, D. L., DRUMMOND, A. J. \& RAMBAUT, A. (2018). Bayesian phylogenetic and phylodynamic data integration using BEAST 1.10. Virus Evolution, 4(1): vey016. https://doi. org/10.1093/ve/vey016

TREITLER, J. T., LÓPEZ-BAUCELLS, A., FARIAS, S. G., TENAÇOL JR., J. F. \& ROCHA, R. (2013). First record of a leucistic piebald Phyllostomus discolor (Chiroptera: Phyllostomidae). Chiroptera Neotropical, 19(1): 11791181.

VERSCHUREN, J. (1955). Un cas d'albinisme complet chez un cheiroptère: Nycteris nana (Andersen). Inst. R. Sci. Nat. Belgique, 31: 1-4.

WEGE, M., POSTMA, M., TOSH, C. A., DE BRUYN, P. J. N. \& BESTER, M. N. (2015). First confirmed record of a leucistic Antarctic fur seal pup born outside the Scotia Arc Islands. Polar Biol., 38: 569-571. https://doi.org/10.1007/ s00300-014-1573-z

ZORTÉA, M. \& CRISTINA SILVA, M. (2017). Albinism in the striped spear-nosed bat Gardnerycteris crenulatum (Chiroptera: Phyllostomidae) with an updated list of albino bats in the World. Mammalia, 82(1): 78-84. https://doi.org/10.1515/mammalia-2016-0080 